\title{
Employment Law System in The Covid-19 and New Normal Pandemic Periods
}

\author{
Citra Resmi Nanda Putri Pratiwi ${ }^{1}$, Tri Lisiani Prihatinah ${ }^{2}$ \\ ${ }^{1,2}$ Universitas Jenderal Soedirman, Purwokerto - Indonesia \\ Email : $\underline{\text { Citraresminanda95@gmail.com }}{ }^{1}, \underline{\text { tisiani@gmail.com }}{ }^{2}$
}

\begin{abstract}
The Ministry of Manpower on April 20, 2020 collected data on workers who were dismissed and sent home during the Covid-19 pandemic, around 2,084,593 workers from 116,370 companies have been sent home. To avoid a legal vacuum during the Covid-19 pandemic, the government issued an employment policy. Based on these problems, the authors conducted a study to find out how the legal steps and policies that have been taken by the government to deal with labor problems during the Covid-19 pandemic in Indonesia. The approach used is normative juridical by analyzing secondary legal materials by understanding law as a set of regulations or positive norms in the statutory system that regulates human life. This research discusses the policy on how the labor law that has been issued by the government is in accordance with the positive law. The government has carried out its obligation to protect the public from dangerous diseases through policies that have been issued since the Covid-19 pandemic until the implementation of the new normal. Although it still requires more specific special rules in an effort to protect employers and workers affected by Covid-19 and the economy in Indonesia.
\end{abstract}

Keywords- Employment Law, Pandemic Covid-19, New Normal.

\section{INTRODUCTION}

The development of law is inseparable from the times and the growth of society. Currently the world is being shocked by the Covid-19 pandemic which has affected various sectors such as education, economy, social and government. The country of Indonesia was also affected by the pandemic. The efforts to prevent the spread of the Covid-19 virus that have been carried out by the Indonesian government include making several new policies through the Presidential Decree and Perppu. Enforcing learning and working at home is one of the solutions so that education and economic activities continue to run, while people who must continue to work outside the home are required to comply with government regulations in accordance with health protocols.

Rules related to physical distancing have been regulated in Government Regulation Number 21 of 2020 concerning Large-Scale Social Restrictions (PSBB), Ministry of Health Regulation (Permenkes) Number 9 of 2020 and Law Number 6 of 2018 concerning Large-Scale Social Restrictions Health Quarantine (PSBB) Article 59, as follows: Enforcement of Large-Scale Social Restrictions is part of the Public Health Emergency response; Large-scale Social Restrictions are aimed at preventing the spread of the ongoing Public Health Emergency disease between people and the wider community in a certain area; Large-scale social restrictions as referred to in paragraph (1) include: school and work vacations, restrictions on religious activities; or, restrictions on activities in public places or facilities; The implementation of largescale social restrictions in coordination and cooperation with various related parties in accordance with the provisions of laws and regulations.

The Ministry of Manpower on April 20, 2020 , has collected data on the number of workers who were dismissed and sent home during the Covid-19 pandemic, it was recorded that around $2,084,593$ workers from 116,370 companies had been sent home. In the formal sector, 1,304,777 workers from 43,690 companies were dismissed and 241,431 workers laid off from 41,236 companies. This policy was taken because most companies suffered losses and as a form of compliance with government regulations related to PSBB. This has led to an increase in the number of unemployed in Indonesia. The economy has become bad because most of the Indonesian population has difficulty earning income during the Covid-19 pandemic. In May there was an increase in the number of homeworkers and layoffs of around 1.7 million people from the formal and informal sectors.[1] According to the Central Statistics Agency, there 
was an increase in the number of unemployed people in February 2020 by around 137.91 million people compared to February last year.[2] Based on the Labor Force Participation rate (TPAK), during February 2020, there was a decrease in TPAK by 69.17 percent and the economy of many workers decreased. There was a difference in TPAK according to gender in February 2020, namely 83.82 percent of men and 54.56 percent of women.

The World Health Organization (WHO) in 1948 also emphasized that human rights for everyone have the highest degree of health. After several amendments were made, one of the articles which emphasized the right to live in physical and spiritual prosperity, to live and have a good and healthy living environment and to obtain health services is article $28 \mathrm{H}$ paragraph 1 . Based on this article, the state automatically has the responsibility and ensure the safety of the community from health hazards that attack. The increase in the number of the workforce is not proportional to the increase in the level of public participation. The government's authority to make decisions is a step that needs to be taken to make decisions as quickly as possible because existing laws are impossible to enforce, causing a long legal vacuum and can endanger the survival of the community. The basis of this authority is the Decision of the Constitutional Court Number 138 / PUU-VII / 2009.

\section{PROBLEMS}

Based on this background, the following problems are formulated:

1. What is the legal policy that has been taken by the government to deal with labor problems during the Covid-19 pandemic and New Normal in Indonesia?

2. What solutions need to be taken by the government to deal with labor problems?

\section{Research Methodology}

Researchers use secondary legal materials, namely data obtained indirectly from sources, but from books, surveys, news or journals that have been published and known to the general public or literature reviews obtained from news, Covid-19 journals, labour journals, Statistics Agency National and other sources as supporting data that can answer questions related to labor issues and legal layoffs during the Covid-19 pandemic. The approach used is juridical normative by using a statute approach to find out legal rules that are related to the object of research with authoritative primary legal material sources such as laws and regulations in force in Indonesia and used as the basis for legal enforcement to be enforced by the community by reviewing or analyzing secondary legal materials by understanding the law as a set of regulations or positive norms in the statutory system concerning human life.[4] Additional data used were the perppu and several regulations taken by the government related to labor regulations during the Covid-19 pandemic

\section{DISCUSSION}

A. Legal Policies that have been carried out by the government to reduce the number of workers who have been laid off during the Covid-19 and New Normal pandemic.

Each company has a work agreement in accordance with existing laws and regulations. The following are the conditions for the validity of the work agreement as regulated in Article 1320 of the Civil Code. Other provisions are in Article 52 paragraph 1 of Law Number 13 Year 2003 concerning Manpower, namely:

1. Agreement of both parties;

2. Ability or ability to take legal actions;

3. The existence of the work that was promised;

4. The agreed work must not conflict with public order, morality and the provisions of the prevailing laws and regulations.

According to Imam Soepomo, labor or employment is an association, both written and unwritten, which relates to an incident when someone works for another person and receives wages, including all people who are able to do work, whether they already have a job in a work relationship or as a self-employed person. workers or those who have not or do not have a job. According to Molenaar, labour or employment is part of everything that applies, which regulates the relationship between workers and employers and vice versa.

The Covid-19 pandemic that hit Indonesia caused new problems in the labour sector, such as:

1. Enforcement of Work From Home (WFH) in accordance with Article 86 paragraph (1) letter a of Law Number 13 of 2013 
concerning Manpower, which means that every worker or laborer has the right to obtain protection for occupational safety and health. The work system is carried out as an effort to limit the number of workers in a room in a company or office related to the application of social distancing and physical distancing;

2. Companies lay off and lay off workers so that they do not have to pay work wages and reduce the risk of even greater losses;

3. Repatriation of Indonesian Migrant Workers who work abroad;

4. The government uses foreign workers who are deliberately brought in and employed to help manage several projects that lack Indonesian Human Resources;

5. Creating legal uncertainty for industrial relations actors in Indonesia.

The implementation of Work From Home (WFH) causes company owners to experience bankruptcy or losses because company income continues to decline and it is difficult to pay employees. Most companies take unilateral policies, both in the formal and internal sectors, namely laying off or laying off workers. Meanwhile, workers who are not affected by layoffs must be granted their rights as workers in accordance with the rules in the Manpower Act. Employers must guarantee security and comfort in working during the Covid-19 pandemic because at the opening of the 1945 Constitution it was explained that the goal of the state is to guarantee general welfare for all Indonesian people.

Regulations issued by the government during the Covid-19 pandemic for the continuity of businesses and workers, are as follows:

1. Ministerial Circular Number M / 3 / HK.04 / III / 2020 concerning Protection of Workers / Laborers and Business Continuity in the Context of Preventing and Overcoming Covid-19. Providing full wages for workers who have to carry out isolation due to being infected with Covid19 and workers who cannot work because they are infected with Covid-19 can provide evidence in the form of a doctor's letter, giving wages in accordance with the Labour Law. Companies that apply the PSBB, wages are paid by agreement;

2.Ministerial Circular Number M / 4 / HK.04 / IV / 2020 concerning Services for the Use of Foreign Workers in Efforts to Prevent the Entry of the Covid-19 Virus. The government has imposed a temporary suspension rule on the permit service process for the use of foreign workers for new applications with the exception of foreigners who will work on national strategic projects and holders of residence permits who are still in Indonesian territory. If the Foreign Worker cannot return to his country because he has entered into a work contract or has worked for the short and long term, an extension can be made based on the submission of an application from the employer;

3.Ministerial Circular Number M / 4 / HI.00.01 / V / 2020 concerning the Implementation of 2020 Religious Holiday Allowances in Companies During the Corona Virus Disease 2019 (Covid-19) Pandemic. ;

4. Circular of the Minister of Manpower of the Republic of Indonesia Number M / 8 / HK.04 / V / 2020 concerning Worker / Labor Protection in the Work Accident Security Program in Cases of Occupational Disease due to Corona Virus Disease 2019 (Covid-19).

Preventive steps that can be taken by the government are to ensure that every employer takes maximum prevention so that there are no cases of Occupational Disease (PAK) by using regulatory standards and Occupational Safety and Health (K3) in accordance with the provisions of laws and regulations. Companies must ensure that workers or labourers who are at risk of a special social security program register them with BPJS Ketenagakerjaan. Company owners or employers minimize layoffs of their workers and lay off some of their workers to reduce the number of losses they experience. Workers' health rights need to be a top priority as stated in Law Number 13 of 2003 concerning Manpower. The government has an obligation to issue policies that are able to protect business owners and workers.

The purpose of the birth of this Law is to provide legal protection for workers / labor, such as Empowering and empowering manpower optimally and more humanely; Realizing equal employment opportunities throughout the region and the provision of manpower who have the ability according to the needs of national and regional development; Providing protection to workers in 
creating welfare; and Improve the welfare of workers and their families. The Circular of the Minister of Manpower and Transmigration Circular Number Circular 907 / Men / PHIPHI / X / 2004 has explained that companies can take preventive steps to suppress massive layoffs, namely, reducing wages and upper level work facilities; Reducing the number of shifts per day; Limit / remove the overtime system; Reducing working hours than usual to maintain workers' stamina; Reducing working days according to the company's production needs; Leave or leave workers on a rotating basis to reduce the number of workers in a workplace; Not renewing the contract for workers whose contract has expired; Providing early retirement for those who have met the requirements, especially those aged 45 years and over who have a greater risk of transmission.

The central and local governments are responsible for covering the lives of those affected by Covid-19 as long as the pandemic is not over. The policies that have been taken by the government are classified as late because many workers who have returned to their areas have been infected with Covid-19 so that they have received rejection from the community. The implementation of the protocol scheme has been carried out by BP2MI which has coordinated with four Ministries / Agencies, namely the Ministry of Transportation, Ministry of Social Affairs, Ministry of Foreign Affairs and the National Disaster Management Agency (BNPB) as the Task Force for the Acceleration of Handling Covid-19 by conducting health checks on Indonesian Migrant Workers ( PMI) at the Port Health Office (KKP) by checking body temperature, quick tests and filling in medical forms to find out travel history or illnesses owned by Indonesian Migrant Workers and workers who are positive for Covid-19 will immediately undergo the self-quarantine process or at the Referral Hospital Government.

Through the Ministry of Foreign Affairs, the government seeks to ensure food or logistics for Migrant Workers in the countries where they work. Providing quarantine places, the need for Covid-19 checks, and facilitation of repatriation in accordance with health protocols determined by the Indonesian government. The social assistance that has been carried out is quite good but there are still a lot of assistance that has not been on target such as direct cash assistance, Pre-Work Card Program, Improvement of the Family Hope program, Cutting electricity rates for those who have lost their jobs, incentives, postponing payment of installments, eliminating taxes for UMKM.

The laid-off workers have been given several social assistance, such as direct cash assistance channeled through their respective regions; Providing a special Pre-Employment Card program for workers who have been officially laid off to make it easier to find new jobs and add expertise in certain fields; Improvement of the Family Hope program; Cutting electricity rates for those who have lost their jobs and those who are less fortunate with several specific criteria; Incentives in the form of postponement of installment payments and tax elimination for MSMEs. The efforts made by the government are in accordance with Article 10 of the Manpower Act Number 13 of 2003. Whereas (1) Job training is carried out by taking into account the needs of the labour market and the business world, both inside and outside of work relations; (2) Job training is held based on training programs that refer to work competency standards; (3) Job training can be carried out in stages.

The government began to impose new normal in parts of the Republic of Indonesia. The government must ensure that companies prevent the development of a pandemic by providing education to workers regarding the prevention of Covid-19 transmission and making innovations to make it easier for consumers to buy and sell transactions using an electronic system. Prioritizing Industrial Relations that can run harmoniously by reducing the number of Termination of Employment (PHK) in accordance with Article 151 paragraph (1) of the Manpower Law. Working time arrangements and savings are necessary to seek mutual agreement without harming any of the parties affected by Covid-19. It is necessary to provide a company security system with cash flow and provide incentives for employees on a regular basis. Companies can make contingency agreements for the impact of the corona which are carried out under the supervision of trade unions and the government. The legality of using civil law, namely Articles 1244 and 1245 of the Civil Code related to Clausula Boiled Sic Stantibus, is a condition that eliminates the obligations of each party in an agreement in the event of a "fundamental change of circumstances" or Force Majeure, namely a fundamental change from a situation that occurs beyond human capacity, such as the impact of the Covid-19 pandemic.

Health workers are in dire need of health protection guarantees. The government must prepare 
sufficient Personal Protective Equipment (PPE) so that it can be used by health workers. There is a need for other laws that provide specific rules that provide legal certainty regarding work safety and legal protection for workers. The legal basis for information transparency is in Law Number 14 of 2008 concerning public information. The local government actively participates in providing information as widely as possible and providing health outreach to prevent the spread of Covid-19. As stated in Article 17, Articles 154 and 155 of Law Number 36 of 2009 concerning health. Regulations that specifically provide a basis for authority for the central and regional governments to convey information, namely articles 79 and 80 of Law Number 6 of 2018 concerning Health Quarantine as a measure to prevent and eradicate public health risks. Socialization must be carried out by the police, TNI and institutions appointed by the state so that the public knows how to handle it properly and increases public awareness of how the spread of Covid-19.

Evaluation of the various regulations that have been issued by the government needs to be done to measure the level of effectiveness of the regulations that have been made. If the policy has not been able to provide legal benefits, it means that the government needs to collect the decision by considering the use of law from various aspects. The effort that needs to be done is to make or make a collective agreement and open a dialogue regarding the condition of the company due to the covid-19. The aim is to discuss the anticipation of facing the worst conditions in work relations. To deal with a worsening work situation due to the economic crisis, labor mitigation is also needed, such as providing training through the assistance of Pre-Work Cards to those who have just graduated from school or Termination of Employment (PHK).[5]

\section{B. Solutions that the Government Needs to Take to Address Labour Problems.}

The policies carried out by the government are good, but special regulations are needed that can provide legal guarantees related to work safety and protect the law for workers. The more workers who are laid off will certainly increase the burden on state finances and reduce the welfare of the community. Providing health insurance for workers who are at high risk of being exposed to Covid-19 is still not optimal to reduce the number of infections and deaths among workers.
In the new normal period, the government must further improve supervision and public participation can play a role in overseeing existing work norms. According to the minister of manpower, Ida Fauziyah, "companies that are required to report employment are 252,880 companies with 13,138,048 workers. The obligations of the labor inspector are to inspect as many as five companies every month or 60 companies in one year according to the Minister of Manpower Regulation No. 33 of 2016 concerning Labor Inspection Procedures and Manpower Regulation No. 1 of 2020 concerning amendments to the Minister of Manpower Regulation No. 33 of 2016.[6] The high number of positives for Covid-19 makes the government and companies need to implement a scheme to prevent the spread of Covid19 which is carried out by providing Work Accident Security (JKK) for workers who are starting to be active and returning to work at the company. Increased health insurance by $\mathrm{K} 3$, such as DK3N, K3 Institutions, Universities, ILO, BP Jamsostek, BPJS Employment, Apindo, and SP / SB is carried out to ensure the safety of workers based on the Circular of the Minister of Manpower Number M / 7 / AS.02.02 / V / 2020 concerning Business Continuity Plans in Facing the 2019 Corona virus Disease Pandemic (Covid-19) and the Covid-19 Transmission Prevention Protocol in Companies.

Work planning is carried out to save business owners by making several efforts by looking at the progress of the business being carried out during the new normal period, predicting the magnitude of the risk of Covid-19 transmission, mitigating risk, communicating or making a special work agreement involving the government, companies and workers, and do a trial run before running his business. The shifting work system is implemented so that there is no need to lay off some workers and can provide wages to workers. The supervision process can be carried out in 2 (two) ways, namely the manual way by checking the performance results or work effectiveness in accordance with the health protocol recommended by the government and online or digital supervision to simplify and minimize the risk of direct contact between supervisors and workers. If companies do not immediately reopen jobs, the number of unemployed in Indonesia will increase and it will be difficult for the government to control. Poverty will widen and many people who are classified as workers of productive age cannot play an active role in the process of economic 
improvement. Government policies such as the preemployment card program can run well if they are carried out maximally so that they can again increase economic growth, especially the import sector abroad.

Figure 1. Table of the number of decreases in the gross household income of the community in a period of one month during the Covid-19 pandemic.

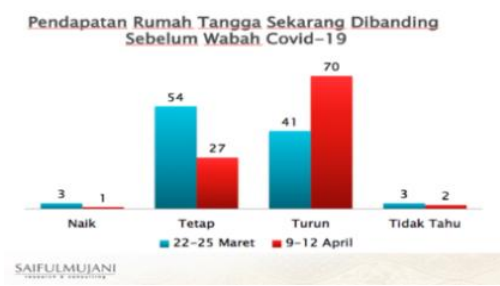

Source: Saiful Mujani Research and Consulting (SMRC), 17 April 2020.

Based on the survey process conducted by Saiful Mujani on April 9 to 12, 2020 by taking 1200 respondents. Produce data that as many as $67 \%$ of Indonesians experience difficulties and their economy is decreasing due to the Covid-19 pandemic. The people most affected are informal workers and daily workers who are paid according to their working hours. The public's response to the policies that have been implemented by the government is that around $52 \%$ of the public thinks that the central government has been fast in suppressing the transmission of the Covid-19 pandemic, while the remaining $41 \%$ think that the government's steps are slow. Each region gave a different response to the results of the survey that had been carried out throughout Indonesia.[7]

If the government does not immediately take a policy, people who are in the middle to lower economic level will find it increasingly difficult to meet their primary needs. Meanwhile, those at the upper economic level do not really feel the significant impact in meeting their primary needs. Chairman of the Expert Team for the Task Force for the Acceleration of Covid-19 Handling, Wiku Adisasmito, said that "The government will reopen nine economic sectors amid the Covid-19 pandemic. These sectors are mining, petroleum, industry, construction, plantation, agriculture and livestock, fisheries, logistics, and transportation of goods because they have a relatively lower risk of Covid19 transmission ".[8]

Workers who experience layoffs are regulated in article 61 of Law No. 13 of 2003 concerning labor, if:
1. The worker has passed away;

2. The working contact period has ended in accordance with the work agreement letter;

3. There is a court decision, namely the State Administrative Court or the establishment of an industrial relations dispute settlement institution that has permanent legal force;

4. There are certain circumstances or events stated in work agreements, company regulations, or cooperation agreements that can cause the termination of the working relationship.

If there is a party that terminates or terminates the work agreement before the end of the stipulated time, then it is obliged to pay compensation to the injured party in the amount of the worker's wages until the deadline for the expiration of the work agreement. Based on the Manpower Act Number 13 of 2003, Article 156 Paragraph 1, it is explained that if a worker experiences a layoff, he / she is entitled to severance pay and an award for working period (UPMK) and compensation for rights (UPH), as follows:

a. The right to annual leave that has not been taken;

b. Moving costs for employees and their families who are moved to a new workplace;

c. Housing and health compensation is set at $15 \%$ of the total severance pay and UMPK that will be received by employees;

d. Other provisions that have been stipulated in the Work Agreement, Company Regulations, and Collective Bargaining Agreement;

The calculation of the amount of severance pay obtained by workers is regulated in article 156 paragraphs 2 and 3 of the Manpower Act Number 13 of 2003, namely:

1. For a service period of less than 1 year, severance pay is paid 1 times the employee's wages in 1 month;

2. Working period of 1 to 2 years, severance pay is paid twice as much;

3 . Working period of 2 to 3 years, severance pay is paid 3 times the wages;

4. Working period of 3 to 4 years, severance pay is paid 4 times the wages;

5. Working period of 4 to 5 years, severance pay is paid 5 times the wages;

6. Working period of 5 to 6 years, severance pay is paid 6 times the wages; 
7. Working period of 6 to 7 years, severance pay is paid 7 times the wages;

8. Working period of 7 to 8 years, severance pay is paid 8 times the wage;

9. Period of more than 8 years, severance pay is paid 9 times wages.

Filing for compensation for workers affected by layoffs refers to Law Number 2 of 2004 concerning Settlement of Industrial Relations Disputes. The provision of wages and other forms of protection for workers is carried out with a minimum wage with postponement of payment if the employer is unable to pay the wages in accordance with statutory provisions. If using a suspension system the company must seek negotiations with the affected workers. To prepare for the new normal order, it is necessary to provide special competency training for human resources, especially for workers who have been laid off. Government policies must be able to provide clear guidelines for industrial relations players during the Covid-19 pandemic. Workers are vulnerable to getting job security, because the company is doing mass layoffs. Article 164 of Law Number 13 Year 2003 concerning Manpower has stipulated the terms of dismissal, namely, companies must be able to provide evidence of financial reports obtained for 2 years with a statement that they have suffered losses. Protection of normative rights for workers must be carried out.

According to the International Labor Organization (ILO) the Covid-19 pandemic caused 195 million people to lose their jobs and the layoffs of company operating hours and the imposition of reduced working hours. In addition, the ILO also provides several recommendations such as:

a. Provide a stimulus to the economy and employment through various fiscal and monetary policies;

b. Providing support to companies, jobs and labor income through social protection, retaining workers and fiscal / tax relief for companies;

c. Protecting workers in the workplace through the application of the principles of Occupational Safety and Health (K3);

d. Using social dialogue to find common solutions through capacity building of employers, laborers and government.

The United Nations (UN) predicts that the impact of an economic setback due to the global Covid-19 pandemic could result in 25 million workers being fired or having their wages cut.[9]
The Task Force Team issued a Circular which came into effect on June 15, 2020, namely Circular Number 8 of 2020 concerning Working Hours Regulations for Adaptation of New Habits Towards a Productive and Safe Society from Covid-19. This regulation contains the division of work hours for workers in the areas of Jakarta, Bogor, Depok, Tangerang and Bekasi (Jabodetabek) with the hope that all agencies will effectively implement a twowave working hour system so that there is no more accumulation of workers in public transportation when leaving and returning to work, as well as to apply physical distancing to the community. Special exemptions are given to workers who have a high risk of contracting Covid-19

The Ministry of Manpower requests that companies and their workers carry out intensive social negotiations and maintain industrial relations during the process of adapting the work environment to new habits issued by the government. The Minister of Health of the Republic of Indonesia made a special guideline listed in Number HK.01.07 / MENKES / 328/2020 concerning Guidelines for the Prevention and Control of Covid-19 in Office and Industrial Workplaces in Support of Business Continuity in Pandemic Situations. The regulation includes a Management Policy in Preventing Covid19 Transmission for workplaces and workers. Forming a team for handling Covid-19 in the workplace by leadership, staff, K3 and Health officers, accompanied by a special decree made by the leadership of the workplace. Company owners or leaders need to provide policies regarding worker procedures to report indications of Covid-19 cases experienced by themselves or other workers with supervision carried out by health workers.

Implement a home work system for employees who do not allow them to work in the office. All workers are required to maintain a distance from each other while working. When workers enter the office or factory, they must pass through the officers at the entrance to check body temperature and provide hand sanitizers. The application of rules for working hours, especially overtime, can weaken the immune system of workers due to lack of rest, companies reduce shift hours that are too strict, especially employees over 45 years. Notification of the use of masks for workers when traveling to the office, at work or returning to their homes.

Companies that provide meals at work are encouraged to provide adequate nutritional intake by 
providing food menus in the form of vegetables and fruit to increase workers' endurance. Health support facilities in the work environment must be available, such as the provision of hand sanitizers and work environment hygiene sanitation, hand washing places in several locations where workers usually pass, and doing physical distancing during activities at least 1 meter. Companies or leaders provide knowledge by conducting a Healthy Living Community Movement (Germas) campaign with a Healthy Lifestyle and Clean and Healthy Living Behavior (PHBS), such as:

1. Washing hands using soap;

2. Teaches etiquette when coughing;

3. Conducting sports together before starting work and basking in the sun during recess;

4. Make it a habit to eat healthy and nutritious foods;

5. Avoiding the use of personal items together.

Education can be done by installing banners, wall magazines, and pamphlets in strategic locations that can be seen by workers, maximizing air circulation in the room so that sunlight can enter, always washing hands using soap and running water. The Minister of Manpower Circular 3/2020 regulates how to prevent the spread and handling of covid-19 in the work environment, as follows: (a) providing guidance and supervision of the implementation of legislation in the field of occupational safety and health (K3); (b) disseminating information to all levels of organizations and related parties who are in the area of guidance and supervision of the Governor; (c) record and report to the relevant agencies every case or suspected covid-19 case in the workplace; (d) order every company leader to anticipate the spread of covid-19 to workers or laborers by taking preventive measures such as clean and healthy living habits by integrating in the K3 program, empowering the Occupational Safety and Health Committee (P2K3) and optimizing service functions occupational health; (e) encouraging every company leader to immediately make preparedness plans in the face of the Covid-19 pandemic, with the aim of minimizing the risk of transmission in the workplace and maintaining business continuity; (f) if there are workers or employers who are at risk, are suspected of, or experience illness due to Covid-19, it is advisable to take steps for handling according to health standards issued by the Ministry of Health.
Legal certainty related to laws and perppu issued by the government related to utility theory according to Jeremy Bentham, namely that law has the goal of benefiting many people. Utrecht also argues that the emphasis of the purpose of law lies in its legal function, namely to ensure legal certainty regarding rights and obligations which are guaranteed by law.[10] According to M Friedman, the legal system is a system consisting of three types such as:

1.Legal Substance, namely the legal content in statutory regulations containing all written or unwritten legal rules;

2.Legal structure, namely legal structure, law enforcers, legal institutions, courts and lawmakers;

3. Legal culture, which is part of the culture and law enforcement, ways of acting and thinking, both aimed at diverting social forces towards law or those that stay away from the law.

The government provides advice to companies to provide data on workers affected by layoffs and workers affected by Covid-19 to join the Pre-employment card program. Article 1 point 16 states that industrial relations is a system of relations formed between actors in the process of producing goods and services consisting of elements from entrepreneurs, workers or laborers, and the government based on the values contained in Pancasila and the Constitution of the State. The Republic of Indonesia 1945. Legislation such as the Minister of Manpower Regulation is needed in order to provide benefits for industrial relations actors and to provide protection for workers' normative rights such as wages, occupational safety and health, rest periods and holiday allowances for workers.

The government shall carry out the supervision of work relations so that they can be proactive in providing incentives for labor inspectors. The way to solve problems related to employment and unemployment is done by increasing the productivity and competence of workers from various sectors in order to enter and increase competitiveness in the labor market and not be inferior to foreign workers. The government needs to develop central and regional partnerships, develop training funds and provide special certificates for competent workers. Improved services in several sectors must be improved so that local and foreign investors can invest and create jobs in Indonesia. Providing job training not only for 
workers in the industrial sector but also for lowermiddle work units so that the lower middle class can participate in advancing the Indonesian economy.

\section{CONCLUSION}

The policies that have been made by the government regarding employment during the Covid-19 pandemic and New Normal are appropriate because if these regulations are not issued, workers and companies will be increasingly affected. Several policies taken by the government include issuing a Ministerial Circular Number M / 3 / HK.04 / III / 2020 concerning Protection of Workers / Laborers and Business Continuity in the Context of Preventing and Overcoming Covid-19, Ministerial Circular Number M / 4 / HK.04 / IV / 2020 concerning Services for the Use of Foreign Workers in Efforts to Prevent the Entry of the Covid19 Virus, Ministerial Circular Number M / 4 / HI.00.01 / V / 2020 concerning the Implementation of 2020 Religious Holiday Allowances in Companies Pandemic Corona Virus Disease 2019 (Covid-19), Circular of the Minister of Manpower of the Republic of Indonesia Number M / 8 / HK.04 / V / 2020 concerning Protection of Workers / Laborers in the Work Accident Security Program in Cases of Work-related Diseases due to Corona Virus Disease 2019 ( Covid-19). The process of resolving problems related to labour and unemployment is carried out by increasing the productivity and competence of workers from various sectors so that they can enter and increase competitiveness in the labor market and are not inferior to foreign workers as well as dividing work hours and reducing workers' overtime hours, providing a sense of justice and carry out labor inspection by enhancing the quality of $\mathrm{K} 3$ inspection norms, employment and improving the application of Jamsostek and work norms. The efforts made by the government aim to save an economy that was difficult to control because many business actors went bankrupt and workers were hit by mass layoffs. The government needs close cooperation in the process of socialization or introduction to the public through mass media and social media coverage.

\section{REFERENCES}

[1] S. Novika, "Corona Serang RI, Pekerja Dirumahkan \& Kena PHK Tembus 1,7 Juta", detikfinance, 2020. [Online]. Available: https://finance.detik.com/berita-ekonomi- bisnis/d-4999246/corona-serang-ri-pekerjadirumahkan--kena-phk-tembus-17-juta/2.

[Accessed: 6- Jun- 2020].

[2] Badan Pusat Statistika, "Keadaan Ketenagakerjaan Indonesia Februari 2020", No. 40/05/Th. XXIII, May, 52020.

[3] Soerjono Soekanto \& Sri Mamudji, Penelitian Hukum Normatif, Suatu Tinjauan Singkat, Jakarta: Rajawali, page 15, 2015

[4] Imam Soepomo, Pengantar Hukum Perburuhan, Jakarta: Djambatan, 1999.

[5] "4 langkah antisipasi PHK akibat pandemi COVID-19 dari segi hukum", The Conversation, 2020. [Online]. Available: https://theconversation.com/4-langkahantisipasi-phk-akibat-pandemi-covid-19-darisegi-hukum-135471. [Accessed: 10- Jun2020].

[6] T. Santia, "Menaker Minta Pengawasan Pekerja Ditingkatkan saat New Normal", liputan6.com, 2020. [Online]. Available: https://www.liputan6.com/bisnis/read/427992 6/menaker-minta-pengawasan-pekerjaditingkatkan-saat-new-normal. [Accessed: 15Jun- 2020].

[7] "Mayoritas Warga Anggap Covid-19 Ancam Penghasilan - SaifulMujani", SaifulMujani, 2020. [Online]. Available: https://saifulmujani.com/mayoritas-wargaanggap-covid-19-ancam-penghasilan. [Accessed: 19- Jul- 2020].

[8] "Pemerintah Sebut Faktor Ekonomi Salah Satu Alasan Terapkan Normal Baru - Nasional Katadata.co.id", Katadata.co.id, 2020. [Online]. Available: https://katadata.co.id/berita/2020/06/10/pemer intah-sebut-faktor-ekonomi-salah-satu-alasanterapkan-normal-baru. [Accessed: 15- Jun2020].

[9] 2020. [Online]. Available: https://www.thejakartapost.com/news/2020/03 /19/pandemic-could-make-another-25million-jobless-un.html. [Accessed: 17- Jun2020].

[10] S. Adiwinata, Penuntun Pengantar Ilmu Hukum, Bandung: Pasundan Law Faculty Press, page 16, 1997. 